\title{
Dok. 3. \\ Przemówienie inauguracyjne nowego przewodniczącego Parlamentu Europejskiego Jerzego Buzka na otwarcie sesji plenarnej PE 15 września 2009 r. w Strasburgu
}

Szanowni Przewodniczący Parlamentu Europejskiego! Szanowni Ministrowie! Szanowni Przewodniczący i Przedstawiciele Instytucji Europejskich! Szanowne Koleżanki, szanowni Koledzy, a przede wszystkim - drodzy Przyjaciele!

Staję dziś przed Wami jako trzynasty Przewodniczący tej izby wybranej w bezpośrednich wyborach. Cieszę się, że są wśród nas poprzedni Przewodniczący: Pan Emilio Colombo, Pan Enrique Barõn Crespo, Pan Egon Klepsch, Pan Klaus Hänsch, Pan José Maria Gil-Robles, Pani Nicole Fontaine, Pan Pat Cox, Pan Hans-Gert Pöttering to wielki zaszczyt, że tu jesteście. Jak powtarza wielu z Was, mój wybór jest również symbolem - symbolem zrealizowanych marzeń obywateli naszej części Europy o jedności kontynentu.

Drogie Koleżanki i Koledzy z Estonii, Łotwy, Litwy, Słowacji, Czech, Wegier, Słowenii, Rumunii i Bułgarii, Cypru i Malty.

Znam i rozumiem niepokoje, potrzeby i oczekiwania tych, którzy niedawno wstępowali do Unii. Znam, bo w moim kraju są podobne. Jednak teraz wspólnie bierzemy odpowiedzialność za przyszłość naszego kontynentu. Nie ma już starej i nowej Europy. Jest nasza Europa! Wspólna Europa! Chcemy, aby była nowoczesna i silna. I aby dostrzegali to nasi obywatele. Wymaga to energii i pracy. Ten cel jest wart wielkiego wysiłku, bo jest przedmiotem marzeń pokoleń Europejczyków. Ja do tej pracy i tego wysiłku jestem gotów, bo marzenia te były również moimi marzeniami.

Szanowne Koleżanki, szanowni Koledzy!

Gdy rozpoczynamy tę kadencje, Europa i my sami - jej przedstawiciele - stoimy przed wieloma wyzwaniami. Musimy im sprostać. I musimy pamiętać, że Parlament Europejski w tych staraniach o lepszą Europę pełni rolę szczególną, nie tylko instytucjonalną, ale i społeczną. Rolę głęboko symboliczną. Parlament Europejski to istota europejskiego systemu demokratycznego. To fundament trwałości i stabilności tego systemu, strażnik idei i wartości, które materializują się nie tylko w naszych decyzjach i ich konsekwencjach, ale i w naszych debatach. Ale Parlament Europejski ma też inne zadanie. Jest to zadanie tworzenia wizji nowej Europy, wizji która wychodzi poza teraźniejszość, poza to, co jest, ku temu co być powinno. By tworzyć i współtworzyć tę wizję trzeba wyobraźni, wiedzy, mądrości, a przede wszystkim odwagi. Hannah Arendt, niemiecka filozofka żydowskiego pochodzenia, twierdziła, że polityka jest jedyną obok religii domeną, gdzie zdarzają się cuda. My w Europie, dokładnie 20 lat temu, widzieliśmy taki cud, dlatego wierzymy w moc odwagi, wyobraźni i mądrości. Myślę, że wszyscy tu zebrani w to wierzą. Z optymizmem patrzę na wyzwania, które przed nami 
stoją. W mojej ocenie są to następujące ważne wyzwania: 1. Kryzys gospodarczy i europejska solidarność, 2. Energia i ekologia, 3. Polityka zagraniczna, 4. Prawa człowieka i system wartości, 5. Nasz Parlament i jego reforma.

Panie posłanki i panowie posłowie!

Najbardziej dotkliwa i trudna jest sprawa kryzysu ekonomicznego. Musimy go pokonać i zrobimy to. Europa przejęła wiodącą rolę, proponując rozwiązania w grupach G-8 i G-20 - rozwiązania, które zachowując nasz model społeczny pomagają światu w naprawie gospodarki. W obliczu globalizacji Europa musi mówić jednym głosem. Musimy właśnie teraz, w czasie kryzysu, szczególnie zadbać o wzrost gospodarczy i przeciwdziałać bezrobociu. Ożywić idee Strategii Lizbońskiej i znaleźć sposoby inwestowania w nowe technologie. W innowacje, edukację i w kapitał ludzki. Ważna jest rola budżetu Wspólnoty, aby europejskie programy badawcze miały jasne priorytety i procedury. W myśl nowego traktatu Parlament i Rada otrzymają takie same uprawnienia budżetowe. Procedura współdecydowania obejmie rolnictwo, rybołówstwo, handel zagraniczny, wymiar sprawiedliwości i sprawy wewnętrzne, dając nam równe uprawnienia także w zakresie wydatków na rolnictwo. Musimy strzec się przed pokusą protekcjonizmu i renacjonalizacji wspólnych obszarów polityki. Polityka spójności musi pozostać priorytetem w następnym budżecie Wspólnoty, jeżeli pragniemy doprowadzić do pełnej integracji ponownie zjednoczonego kontynentu. Jednolity rynek jest naszym wielkim osiągnięciem.

Musimy go bronić i konsolidować, aby Europa pozostała konkurencyjnym kontynentem. Oznacza to wzmocnienie, nie zaś osłabienie integracji europejskiej. Miejmy odwagę głoszenia własnych przekonań. Wspólnoty, którą tworzymy nie da się ożywić, zrozumieć i nie da się w niej żyć bez dwóch elementów: solidarności i spójności społecznej. Nie ma bowiem prawdziwej wspólnoty bez troski o wszystkich, zwłaszcza tych najsłabszych: bezrobotnych, niewykształconych, mieszkających daleko na prowincji. Przeciwdziałanie bezrobociu jest głównym celem prezydencji szwedzkiej. Będziemy jej w tym energicznie pomagać. Po tamtej stronie żelaznej kurtyny krzyczeliśmy kiedyś na ulicach: Nie ma wolności bez solidarności. Teraz możemy powiedzieć: Bez solidarności nie ma także wspólnoty. Nie będzie też nowoczesnej, silnej Europy.

Szanowni Przyjaciele,

Nie przezwyciężymy kryzysu ekonomicznego bez potężnego potencjału intelektualnego, ekonomicznego, twórczego kobiet. Kryzys demograficzny wymaga wzmocnienia rodziny i dzietności. Musimy zadbać o to, aby kobiety nie musiały poświęcać kariery zawodowej dla rodziny i wychowania dzieci. By pokonać kryzys demograficzny, a zarazem kontynuować demokratyczne, zasady musimy też być wspólnotą otwartą. Imigracja zawsze przynosiła Europie korzyści. Musimy zaproponować rozwiązania, dzięki którym będziemy mogli zapraszać imigrantów, stwarzać warunki integracji, ale też oczekiwać od nich, że będą oni sami na tę integrację otwarci.

Szanowne Koleżanki, Szanowni Koledzy,

Stoimy w obliczu kryzysu energetycznego. Europejczycy mogą nie rozumieć geopolityki, rozumieją natomiast, że wyłączono im ogrzewanie. Musimy kontynuować dy- 
wersyfikację źródeł energii zwiększając inwestycje w odnawialne źródła energii i paliwa kopalne. Energia atomowa pozostaje do dyspozycji i do decyzji Państw Członkowskich. Musimy rozszerzyć sieć rurociagów zewnętrznych, abyśmy nie byli zależni od jakiegokolwiek państwa. Musimy zwiększyć wzajemne połączenia między naszymi sieciami gazowymi i elektrycznymi. A także rozważyć możliwość wspólnych zakupów gazu, tak aby powstał rzeczywisty, europejski rynek solidarności energetycznej. Myślę, że nadszedł czas prawdziwej, wspólnej polityki energetycznej Unii. Będę o to zabiegał. Podobnie przecież powstanie Europejskiej Wspólnoty Węgla i Stali w 1951 roku stało się zalaż̇kiem naszej wspólnoty. Robert Schuman oświadczył wtedy, że „solidarność produkcji, która się $w$ ten sposób powstanie, sprawi, że wszelka wojna [...] stanie się nie tylko nie do pomyślenia, ale również w praktyce niemożliwa". To była idea pierwotna tej wspólnoty.

\section{Drodzy Przyjaciele,}

Nasza polityka energetyczna musi uwzględniać zagrożenia środowiskowe związane ze zmianami klimatycznymi. Potrzeba nam zielonej rewolucji i etyki samoograniczenia się. Parlament Europejski przewodzi debacie na ten temat. $Z$ wieloma koleżankami posłankami i kolegami posłami pracowałem w komisji tymczasowej do spraw zmian klimatycznych. Znacie moje poglądy i wiecie, że będę z Wami współpracował na rzecz kompromisu w Kopenhadze.

\section{Szanowne Posłanki i Szanowni Posłowie,}

Jesteśmy ważnym podmiotem na arenie międzynarodowej. Tego oczekują od nas nasi obywatele. Więcej Europy potrzeba nam nie tylko w granicach Unii Europejskiej, ale również na świecie. Spójna, skuteczna polityka zagraniczna, dotycząca wizji globalnego ładu, powinna stanowić poważne wyzwanie dla obecnej kadencji Parlamentu. Jean Monnet powiedział kiedyś, że każdy ma ambicję. Pozostaje jedynie pytanie, czy ambicja ta służy do tego, aby kimś być, czy aby czegoś dokonać. Miejmy ambicję dokonania czegoś w tej kadencji. A co jest najważniejsze? Po pierwsze: Aktywna polityka wobec południowych i wschodnich sąsiadów Unii Europejskiej. W tym celu należy kontynuować prace w ramach zgromadzenia międzyparlamentarnego EMPA i podjąć działania w ramach zgromadzenia Euronest. Po drugie: Promować demokrację i wzorce dobrego rządzenia. Musimy wykorzystać zgromadzenia miedzyparlamentarne i nasze delegacje, aby organizować szczyty parlamentarne przed bilateralnymi szczytami Unii. To ważne, bo Parlament Europejski będzie współdecydował o większej liczbie polityk. Dobrym przykładem takiej współpracy jest EUROLAT.

Po trzecie: Pora na prawdziwe transatlantyckie partnerstwo parlamentarne i wspólne budowanie nowych ram globalnego ładu. Będę dążyć do wzmocnienia więzi z Kongresem Stanów Zjednoczonych na wszystkich szczeblach. Po czwarte: Pracować nad naszym strategicznym partnerstwem z Rosją nie zapominając, podobnie jak w stosunkach z Chinami, że względy gospodarcze i polityczne nie mogą być ważniejsze niż prawa człowieka, praworządność i demokracja. Jako przewodniczący tej Izby w pełni zaangażuję się $\mathrm{w}$ dialog $\mathrm{z}$ rosyjskimi partnerami. Także $\mathrm{w}$ ramach nowej strategii dla Morza Bałtyckiego. Po piąte: Powinniśmy wzmocnić nasze stosunki z Indiami i pozostałymi wschodzącymi potęgami, takimi jak Brazylia i Republika Południowej Afryki. 
Indie muszą być naszym partnerem zarówno w sferze gospodarczej, jak i politycznej. Po szóste: Kluczem do globalnej stabilizacji pozostaje Bliski Wschód. Europa musi odgrywać aktywną rolę w tym regionie. Po siódme: Rozszerzenia to jedna z naszych najbardziej udanych strategii politycznych. Czy ktoś z naszych europejskich przodków mógł się cieszyć tak trwałym pokojem i dobrobytem jak my teraz? Chorwacja, a może i Islandia, wydają się dzisiaj być najbliżej członkowstwa. Po ósme: Unia jest największym dawcą pomocy na świecie. Musimy sporządzić bilans naszych aktualnych i potencjalnych beneficjentów i pamiętać o wypełnianiu zobowiązań wobec nich, zgodnie z milenijnymi celami rozwoju. Zamykając drzwi przed niektórymi przybyszami, nie zamykajmy serc i starajmy się, na ile możemy sprawić, aby życie w ich krajach zbliżało się do naszych, europejskich standardów. Po dziewiąte: Musimy zadbać o wzmocnienie misji wysyłanych przez Unię w ramach europejskiej polityki bezpieczeństwa i obrony, których przez ostatnie 6 lat było aż dwadzieścia dwie. Powinny być one wyposażone w jasny mandat i niezbędne do działania środki. Parlament Europejski chce zagwarantować ściślejszą kontrolę i nadzór nad nimi. Rozszerzone uprawnienia budżetowe, które Parlament nabędzie na mocy Traktatu z Lizbony, mogą poprawić naszą elastyczność w zakresie przeznaczania funduszy na potrzebne i popierane przez nas misje.

Szanowne Koleżanki, szanowni Koledzy!

Wdrożenie nowego Traktatu musi być naszym priorytetem w najbliższej przyszłości. Zobowiązuję się do przygotowania Parlamentu do funkcjonowania zgodnie $\mathrm{z}$ nowymi przepisami w dniu wejścia Traktatu w życie. Ale bez względu na Traktat, czujemy potrzebę zmian. Czujemy potrzebę wprowadzenia bardziej dynamicznego parlamentaryzmu w naszej izbie. Jako przewodniczący Parlamentu pragnę opierać się na istotnej pracy, jaka w dziedzinie reformy parlamentarnej została $w$ ostatnich latach zainicjowana przez moich poprzedników. Ale musimy iść dalej. Zrobię wszystko, aby zwiększyć przestrzeń dla kreatywnej debaty politycznej na forum naszej Izby. Osobiście jestem zdecydowanym zwolennikiem częstszego zgłaszania wniosków o wystapienie z sali, gdyż w ten sposób można ożywić debaty plenarne. Uważam to za szczególnie ważną gwarancję praw mniejszości.

Najważniejszym brakującym ogniwem procesu reformy jest poprawa stosunków z pozostałymi instytucjami UE - Komisją Europejską i Radą Ministrów. Znaczna część mojej kadencji będzie poświęcona tej sprawie. Jako przewodniczący będę dążył do opracowania nowego modelu partnerstwa z Komisją Europejska, do nasilenia parlamentarnej kontroli władzy wykonawczej oraz do zwiększenia odpowiedzialności organów wykonawczych przed Parlamentem. W lipcu zaprosiłem przewodniczącego Komisji do udziału w turze pytań, która odbywałaby się w Parlamencie co miesiąc i podczas której zadający pytania byliby wyznaczani na podstawie zgłoszeń z sali. Proponuję, abyśmy zaczęli te debaty jak najszybciej. Dwa tygodnie temu przewodniczący Barroso przekazał nam swoje ,polityczne wytyczne” na drugą kadencję. To znacząca innowacja. To akceptacja logiki, wedle której to Parlament Europejski wybiera przewodniczącego Komisji. Przyjmuję to $z$ dużym zadowoleniem.

Zachęciłem także komisje parlamentarne do dokonania przeglądu nieprzyjętego wciąż ustawodawstwa i zbadania, czy nowa Komisja zamierza porzucić, zmienić czy też podtrzymać swe wnioski legislacyjne. Zachęcam także komisje do poważnej dys- 
kusji o przyszłej strategii politycznej, tak aby przesłuchania desygnowanych komisarzy opierały się również na szczegółowym planie ustawodawczym, a nie wyłącznie na ocenie ich życiorysów i doświadczenia zawodowego. Musimy zacieśnić stosunki z Radą Ministrów. Aby były wiarygodne, muszą odzwierciedlać fakt, że w dzisiejszej Unii Europejskiej Parlament jest prawdziwym ustawodawcą. Musimy też wspólnie pracować nad problemami instytucjonalnymi wynikającymi z Traktatu z Lizbony, Chodzi o rozszerzenie procedury współdecyzji, nowy system komitologii, mianowanie nowego wysokiego przedstawiciela i wiceprzewodniczącego Komisji, o demokratyczną kontrolę nad nową służbą działań zewnętrznych oraz sposób traktowania na posiedzeniach plenarnych nowej „podwójnej prezydencji Rady”. Nasze stosunki z 27 parlamentami krajowymi w Unii Europejskiej powinny rozwijać się w tym samym duchu. W ostatnich latach mamy tendencję wzrostową w naszej współpracy, a Traktat z Lizbony jeszcze bardziej wzmocni nasze kontakty i dowartościuje ich rolę, tak by powstawały przepisy przyjazne dla obywatela. Doskonałym przykładem takiej współpracy pomiędzy Parlamentem Europejskim a parlamentami krajowymi jest Program Sztokholmski, dotyczący wymiaru sprawiedliwości i bezpieczeństwa obywateli. Pragnę kontynuować zmiany w wykorzystaniu personelu i wydatków Parlamentu zmierzające w kierunku bezpośredniego zaangażowania w działalność programową. Bogactwo i siła naszej izby to także różnice: narodowe, mentalnościowe i językowe, i dlatego posłowie powinni mieć możliwość wypowiadania się w języku ojczystym, jeśli sobie tego życzą, aby właściwie reprezentować swych wyborców.

Szanowne Posłanki, Szanowni Posłowie,

Trzeba ciaggle pamiętać, że Unia to nie tylko wyzwania przyszłości i wizje coraz większego dobrobytu i stabilizacji. To przede wszystkim prawa człowieka. Z niepokojem obserwuję napięcia w relacjach pomiędzy Słowacją a Węgrami, dotyczące mniejszości narodowych. Chciałbym zadeklarować moją pomoc w rozwiązaniu tego sporu zgodnie z wartościami, w które głęboko wierzymy i które są zgodne z przekonaniami naszego Parlamentu. Dobrym przykładem takich działań jest nagroda im. Sacharowa, która wyłoniła liderów praw człowieka, którzy stanowią dziś podstawę czegoś co nazywam ,siecią Sacharowa” i którą zamierzam rozwijać. Chcę również, abyśmy kontynuowali ideę Domu Historii Europejskiej, zainicjowaną przez mojego poprzednika. Chciałbym, abyśmy sobie jeszcze raz, tu w tej Izbie przypomnieli, ze Unia to wspólnota ideałów i wartości i że na tej bazie ją zbudowaliśmy.

Szanowne Koleżanki, Szanowni Koledzy!

Jestem zdecydowany podjąć działania na rzecz zapewnienia wszystkim komisjom i delegacjom dostępu do telewizji satelitarnej i internetowej. Musimy przyjrzeć się sposobowi przeprowadzania wyborów europejskich. Powinniśmy na przykład nalegać na wykorzystanie nowych technologii podczas wyborów, aby zwiększyć udział obywateli. Pora również rozpocząć dyskusję na temat europejskich partii politycznych. Obywatele powinni wiedzieć, na kogo głosują - nie tylko w swoich krajach, ale również w wymiarze europejskim. Dużą wage przywiązuję do współpracy z Konferencją Przewodniczących Grup Politycznych. Będziemy wspólnie i solidarnie ponosić odpowiedzialność za działania naszej izby, razem z 14 wiceprzewodniczącymi, którym 
dziękuję za deklarację współpracy. Doceniam partnerstwo w osobach przewodniczących naszych komisji parlamentarnych. Chciałbym, aby przewodniczacy stałych delegacji międzyparlamentarnych mieli możliwość wpływać w znaczący sposób na politykę zagraniczną Unii. Z kwestorami będziemy dbać o budżet Parlamentu. Ale przede wszystkim liczę na współpracę $z$ Wami, Koleżanki i Koledzy. Jako przewodniczący PE mam świadomość, że biorę odpowiedzialność za stworzenie Wam dobrych warunków do pracy. Ale też gorąco nawołuję Was wszystkich do podjęcia jej trudu.

Szanowni Państwo,

Dla większości z nas Traktat lizboński jest oczekiwanym rozwiązaniem instytucjonalnym. Przynosi on większą sprawność Unii w rozwiązywaniu bieżących problemów i przynosi zbliżenie europejskich instytucji do obywateli. Bronisław Geremek, którego nie ma już wśród nas, a którego imieniem nazwaliśmy główny plac wewnątrz naszego strasburskiego parlamentu, lubił cytować znane powiedzenie, że europejska integracja jest jak jazda na rowerze: Trzeba cały czas pedałować do przodu, aby utrzymać równowagę i panować nad kierunkiem jazdy. To dokładnie pokazuje jak bardzo potrzebna nam jest ratyfikacja Traktatu z lizbony.

Drodzy Przyjaciele!

Niecały tydzień temu byłem $w$ polskim parlamencie na obchodach 20 rocznicy powstania pierwszego niekomunistycznego rządu Tadeusza Mazowieckiego w naszej części Europy. To bardzo wzruszająca rocznica, bo od tego momentu zaczął się błyskawiczny rozpad totalitarnego systemu w kolejnych krajach Europy Środkowej. To był pierwszy taki wyłom, który pozwolił obalić dzielący Europę mur.

Drogie Koleżanki i Koledzy,

Przemawiam dziś w Strasburgu, stolicy regionu, którego los bardzo przypomina los mego Śląska, regionu przygranicznego, którego mieszkańcy często musieli zmieniać obywatelstwo, mimo że nie zmieniali miejsca zamieszkania. Uroczyście ślubuję, że przewodnicząc Parlamentowi w najbliższych latach, będę Waszym ambasadorem, niosącym obywatelom Europy i świata przesłanie zjednoczonego ponownie kontynentu. Pracujmy razem w poszukiwaniu konkretnych i praktycznych rozwiązań dla wielkich wyzwań, przed którymi stoi dziś Europa i świat. Niech będzie to praca nad urzeczywistnieniem naszych marzeń. Przystąpmy więc do niej z entuzjazmem, wiedzą i odwaga.

Bo to jest nasza Europa: Wspólna. Nowoczesna. Silna Europa. 